\title{
Constraints in Using Kisan Mobile Advisory Service as Perceived by Farmers in Latur District of Maharashtra, India
}

\author{
M.B. Shinde*, D.D. Suradkar and M.B. Gawali \\ Department of Extension Education, College of Agriculture, Latur, Vasantrao Naik \\ Marathwada Krishi Vidyapeeth, Parbhani-431402 (M.S.), India \\ *Corresponding author
}

\begin{tabular}{|l|}
\hline Key w ord s \\
Utility perception, \\
KMAS, KVK \\
\hline Article Info \\
\hline Accepted: \\
04 June 2019 \\
Available Online: \\
10 July 2019 \\
\hline
\end{tabular}

A B S T R A C T

Information Communication Technology (ICT) is today becoming as important as food. Even in rural India, ICTs are having a profound impact in changing the rationale of development activities and strategies. Inspite of these farmers abstain from using it due to various constraints. In this view, a study was conducted to analyze constraints faced by farmers in using KMAS in Latur district of Maharashtra state, India. A total of 120 respondents constituted sample size were selected through proportional sampling technique. The data collection was done with the help of structured schedule by personal interview of the respondents. Results of the study revealed that majority $(51.16 \%)$ of the users expressed that clarification of messages is difficult, poor network connectivity, irregular charging of mobile due to electricity problem and difficult to operate mobile phone as reported by 46.67 per cent, 32.50 per cent and 19.16 per cent respectively. The study recommends the need for considering constraints faced by farmers as they influence the utility perception of KMAS.

\section{Introduction}

The Kisan Mobile Advisory Service (KMAS) is started by ICAR with the aim of passing the agricultural information to maximum number of farmers in local language through SMS free of cost. It is operated by KVKs all over the India. Subject areas of KMAS are Agronomy, Plant protection, Horticulture, Animal science, Home science, Dairy. Advantages of KMAS are farmers can get free information, location specific information delivery, provide information in local language and cost effective. KMAS is started by ICAR with the aim of passing the agricultural information to maximum number of farmers in local language through SMS free of cost. It is operated by KVKs all over the India. Subject areas of KMAS are Agronomy, Plant protection, Horticulture, Animal science, Home science, Dairy, etc. KVK is using Kisan Portal, Ministry of Agriculture, Government 
of India to send the SMS to the farmers. Information Communication Technology (ICT) is today becoming as important as food. Even in rural India, ICTs are having a profound impact changing the rationale of development activities and strategies. Inspite of these farmers abstain from using it due to various constraints. A national survey of farmers found that only 40 per cent of farmer households accessed information about modern agricultural techniques and inputs (NSSO, 2005). So keeping these points in mind the study was mainly focused to reveal the constraints associated with use of KMAS by the farmers of Latur district.

\section{Materials and Methods}

Population for the study comprised of respondents who were subscriber of Kisan Mobile Advisory Service in Latur district. From latur district Latur, Ausa and Renapur tahsils were selected purposively because more number of farmers in these tahsils were using KMAS. Three villages from each selected tahsils were selected on the basis of higher number of subscriber farmers of KMAS. Tahsil wise list of subscriber farmers was obtained from KVK Latur. Proportionate sampling method used in selection of respondents, thus total sample size was one hundred and twenty respondents which who are subscribers of KMAS. One shot case study method of ex-post-facto research design was adopted for this study. The data were collected with the help of structured schedule by personal interview of the respondents.

\section{Results and Discussion}

With respect to the constraints faced by the farmers, it was observed from the Table 1 that majority $(51.16 \%)$ of the users expressed that clarification of messages is difficult was the foremost constraint in using KMAS. This was because there was no feedback cell or helpline centre. Poor network connectivity (46.67\%) was the second most constraint. This was because in the villages range problem. Irregular charging of mobile due to electricity problem $(32.50 \%)$ was the third constraints. This was because there is a load shading problem occurs in villages.

Whereas, difficult to operate mobile phone $(19.16 \%)$, information is sometime not relevant $(17.50 \%)$, KMAS SMSs were not timely $(16.67 \%)$, difficult to understand technical words in the messages $(08.34 \%)$ per cent and adoption of KMAS messages is riskey $(07.50 \%)$ were the less important constraints faced by the farmers.

Table.1 Distribution of the respondents according to the constraints faced by users while using Kisan Mobile Advisory Service

$\mathrm{N}=120$

\begin{tabular}{|c|l|c|c|c|}
\hline $\begin{array}{c}\text { SI. } \\
\text { No. }\end{array}$ & \multicolumn{1}{|c|}{ Constraints } & Frequency & Percentage & Rank \\
\hline $\mathbf{1 )}$ & $\begin{array}{l}\text { Clarification of the messages is difficult if any } \\
\text { doubt arises. }\end{array}$ & 65 & 54.16 & I \\
\hline $\mathbf{2 )}$ & $\begin{array}{l}\text { Difficult to understand technical words in the } \\
\text { messages. }\end{array}$ & 10 & 08.34 & VII \\
\hline $\mathbf{3 )}$ & Information is sometime not relevant. & 21 & 17.50 & V \\
\hline $\mathbf{4 )}$ & Poor network connectivity. & 56 & 46.67 & II \\
\hline $\mathbf{5 )}$ & KMAS SMSs were not timely. & 20 & 16.67 & VI \\
\hline $\mathbf{6 )}$ & Difficult to operate mobile Phone. & 39 & 32.50 & III \\
\hline $\mathbf{7 )}$ & $\begin{array}{l}\text { Irregular charging of mobile due to electricity } \\
\text { problem. }\end{array}$ & 09 & 7.50 & VIII \\
\hline $\mathbf{8 )}$ & Adoption of KMAS messages is risky. & & & \\
\hline
\end{tabular}


Though these constraints were face by less number of farmers but might be due to the fact Latur district is having availability of various facilities. There are diversified cropping sequence in the district. A critical analysis of constraints as perceived by farmers in using KMAS that majority $(51.16 \%)$ of the users expressed that clarification of messages is difficult was the foremost constraint in using KMAS followed by Poor network connectivity (46.67\%), irregular charging of mobile due to electricity problem $(32.50 \%)$ were the major constraints faced by the farmers and ranked I, II and III, respectively.

These constraints can be overcome by providing feedback cell in KMAS regarding the services. The network area should be extended to the rural as well as remote area. To overcome the problem of irregular charging of mobile due to electricity problems.

\section{References}

Dhakar, K. S., (2012). A study on utility perception of farmers in relation to modern mass media under information communication technology in Rewa district. M.Sc. (Agri.) Thesis, JNKVV, Jabalpur.

Kanavi, S. P., (2014). An analysis of Kisan
Mobile Advisory Services (KMAS) of Krishi Vigyan Kendra. M.Sc. (Agri.) Thesis, Univ. Agric. Sci., Dharwad

NSSO. 2005. Situation assessment survey of farmers: Access to modern technology for farming. National sample survey, 59th round report, 499 (59/33/2). New Delhi: GOI. Retrieved on 14.05.2013 http://www.ifpri.org/sites/default/public ations/ifpride00729.pdf

Patel, M. R. Patel, M. V.and Patel, R. A., (2015).Assessment of Kisan Mobile Advisory (KMA) Service for Dissemination of Agriculture Information in Mehsana District; Gujarat. International Journal on Recent and Innovation Trends in Computing and Communication 3(7): 4599-4602.

Patil, K.V., (2016). Utilization pattern of Kisan Mobile Advisory Service by the farmers of Banaskantha district. M.Sc. Thesis. Sardarkrushinagar Dantiwada Agricultural University, Sardarkrushi nagar (India).

Patil, K.V., Patel, V.T. and Prajapati, R.R., (2017). Constraints in Using Kisan Mobile Advisory Service as Perceived by Farmers in Banaskantha District of Gujarat, India.

Int.J.Curr.Microbiol.App.Sci. 6(11): 23 7-240.

\section{How to cite this article:}

Shinde, M.B., D.D. Suradkar and Gawali, M.B. 2019. Constraints in Using Kisan Mobile Advisory Service as Perceived by Farmers in Latur District of Maharashtra, India. Int.J.Curr.Microbiol.App.Sci. 8(07): 177-179. doi: https://doi.org/10.20546/ijcmas.2019.807.022 